\title{
Selection of Metarhizium spp. Brazilian isolates to control Rhipicephalus microplus ticks: in vitro virulence tests and conidiogenesis
}

\author{
Seleção de isolados Brasileiros de Metarhizium spp. para \\ controle do carrapato Rhipicephalus microplus: testes de \\ virulência in vitro e conidiogênese
}

\author{
Giselle Arieiro Jones' ${ }^{1}$, Wendell Marcelo de Souza Perinotto² ${ }^{2}$ Mariana Guedes Camargo ${ }^{3}$, Patrícia Silva Golo ${ }^{3}$ \& \\ Vania Rita Elias Pinheiro Bittencourt ${ }^{3}$ \\ 'Veterinarian, Msc. Departamento de Parasitologia Animal (DPA), Instituto de Veterinária (IV), Universidade Federal Rural do Rio \\ de Janeiro (UFRRJ), Seropédica, RJ, Brasil. \\ 2 Veterinarian, DSc. Centro de Ciências Agrárias, Ambientais e Biológicas, Universidade Federal do Recôncavo da Bahia (UFRB), \\ Cruz das Almas, BA, Brasil. \\ ${ }^{3}$ Veterinarian, Dsc. DPA, IV, UFRRJ, Seropédica, RJ, Brasil.
}

\begin{abstract}
This study aimed to select Metarbizium spp. isolates to control Rhipicephalus microplus ticks by analyzing their in vitro virulence against $R$. microplus eggs, larvae, and engorged females as well as their ability to produce aerial conidia on potato dextrose agar (PDA). After the treatment of $R$. microplus eggs with the highest fungal concentration $\left(10^{8}\right.$ conidia. $\left.\mathrm{ml}^{-1}\right)$, most of the eleven tested isolates reduced the larval hatching compared to the control group, except $M$. anisopliae s.l. ARSEF 2211 and ARSEF 3641. M. anisopliae s.l. isolates ARSEF 729, ARSEF 760, ARSEF 929, and ARSEF 3643 exhibited the best results in the egg bioassay. In the bioassay with larvae, the entomopathogenic fungal isolates yielded average larval mortality ranging from 0.1\% to $98.9 \%$ and from $23.9 \%$ to $99.9 \%$ five and fifteen days after the treatment, respectively. ARSEF 552, ARSEF 729, ARSEF 929, and ARSEF 3643 yielded the highest larval mortality. Analysis of the bioassay with $R$. microplus engorged females found that the different isolates negatively impacted the egg mass weight, larval hatching percent, egg production index, and nutritional index. The percent of tick control ranged from 5.32\% to 70.83\%, and the best tick control rates were caused by M. anisopliae s.l. ARSEF 3643 (70.83\%), ARSEF 3641 (62.87\%), and ARSEF 729 (64.27\%). The highest conidiogenesis on PDA was observed for $M$. anisopliae s.l. ARSEF 3641 and $M$. pingshaense ARSEF 552. The isolates ARSEF 729 and ARSEF 3643 are considered promising candidates for field applications against $R$. microplus ticks.
\end{abstract} Keywords: biological control, entomopathogenic fungi, cattle tick.

\section{Resumo}

Este estudo teve como objetivo selecionar isolados de Metarhizium spp. para controlar carrapatos Rhipicephalus microplus por meio da análise de sua virulência in vitro contra ovos, larvas e fêmeas ingurgitadas, bem como sua capacidade de produzir conídios aéreos em ágar dextrose de batata (PDA). Após o tratamento dos ovos de $R$. microplus com maior concentração fúngica (10 ${ }^{8}$ conídios.ml-1), a maioria dos onze isolados testados reduziu a eclosão larval em relação ao grupo controle, exceto M. anisopliae s.l. ARSEF 2211 e ARSEF 3641. M. anisopliae s.l. os isolados ARSEF 729, ARSEF 760, ARSEF 929 e ARSEF 3643 exibiram os melhores resultados no bioensaio com ovo. No bioensaio com larvas, os isolados fúngicos entomopatogênicos apresentaram mortalidade larval média variando de 0,1\% a 98,9\% e de 23,9\% a 99,9\% cinco e quinze dias após o tratamento, respectivamente. ARSEF 552, ARSEF 729, ARSEF 929 e ARSEF 3643 produziram a maior mortalidade larval. A análise do bioensaio com fêmeas ingurgitadas de $R$. microplus mostrou que os diferentes isolados impactaram negativamente o peso da massa de ovos, a porcentagem de incubação larval, o índice de produção de ovos e o índice nutricional. A porcentagem de controle de carrapatos variou de 5,32\% a 70,83\%, e as melhores taxas de controle de carrapatos foram causadas por M. anisopliae s.l. ARSEF 3643 (70,83\%), ARSEF 3641 (62,87\%) e ARSEF 729 (64,27\%). A maior conidiogênese em PDA foi observada para $M$. anisopliae s.l. ARSEF 3641 e $M$. pingshaense ARSEF 552. Os isolados ARSEF 729 e ARSEF 3643 são considerados candidatos promissores para aplicações de campo contra o carrapato $R$. microplus.

Palavras-chave: controle biológico, fungos entomopatogênicos, carrapato de bovinos.
How to cite: Jones, G. A., Perinotto, W. M. S. Camargo, M. G., Golo, P. S., \& Bittercount, V. R. E. (2021). Selection of Metarhiziumspp. Brazilian isolates to control Rhipicephalus microplus ticks: in vitro virulence tests and conidiogenesis. Brazilian Journal of Veterinary Medicine, 43, e002O2O. https://doi.org/10.29374/2527-2179.bjvm002020

Received: October 23, 2020.

Accepted: December 23, 2020

\section{*Correspondence}

Vania Rita Elias Pinheiro Bittencourt Departamento de Parasitologia Animal, Instituto de Veterinária, Universidade Federal Rural do Rio de Janeiro - UFRRJ BR 465, Km 7, Seropédica CEP 23890-000 - Rio de Janeiro (RJ), Brasil E-mail: vaniabit@ufrrj.br
Copyright Jones et al. This is an Open Access article distributed under the terms of the Creative Commons Attribution Non-Commercial License, which permits unrestricted non-commercial use, distribution and reproduction in any medium provided the original work is properly cited. 


\section{Introduction}

Rhipicephalus microplus (Canestrini, 1887) (Acari: Ixodidae) Murrel \& Barker, 2003, popularly known as the cattle tick, is an import ectoparasite in Brazilian livestock and several other tropical countries. The annual economic losses in Brazil related to the parasitism of this tick are estimated at 3.24 billion dollars and are related to the damages in the leather, transmission of pathogens, reduction in milk and meat production, loss of weight gain, and expenditures on the use of chemical acaricides used to control it (Grisi et al., 2014).

Historically the most common and effective practice to control $R$. microplus ticks in cattle farming has been the use of chemical acaricides, but the evolution of $R$. microplus populations resistant to these acaricides has caused great concern among livestock farmers and government agencies (Andreotti et al., 2011). Several studies have reported resistance of $R$. microplus to the chemical acaricides in almost all classes of products available for tick control in Brazil, including multiple resistance in some field populations (Klafke et al., 2017; Reck et al., 2014). The factors that lead to this development include the indiscriminate use of acaricides, applications with incorrect doses, and delay in initiating treatment (Klafke, 2008).

The growing global concern about environmental contamination and the market for chemical-free foods has contributed to the development of alternative control methods for the R. microplus tick (Samish et al., 2004). One of the alternatives may be the use of entomopathogenic fungi against different life stages of this tick (Wassermann et al., 2016). Fungi are more studied and used microorganisms for biological control than viruses or bacteria (Thomas \& Read, 2007).

The genus Metarbizium is composed of entomopathogenic fungi that are generally greenish, often isolated from soils in tropical and temperate regions, and can colonize arthropods (Bischoff et al., 2009). In vitro (Bahiense et al., 2006; Bittencourt et al., 1994a, 1994b; Perinotto et al., 2014; Perinotto et al., 2017; Quinelato et al., 2012) and in vivo studies (Camargo et al., 2014, 2016; Marciano et al., 2020; Mesquita et al., 2020; Samish et al., 2014; Webster et al., 2015) have already demonstrated its efficiency to control R. microplus with positive perspectives for its use in the field.

Considering the problems associated with the massive use of chemical acaricides and the current knowledge about the entomopathogenic fungi, screening non-exotic fungal isolates with outstandingly biocontrol traits is crucially important to obtain increased effectiveness in tick biocontrol to support the increase of fungal-based biological products developed exclusively to be used against ticks.

Most mycoinsecticides produced currently in Brazil are based on aerial conidia produced by solid substrate fermentation technologies (Mascarin et al., 2019). The capacity of isolates to produce conidia is an important trait for field use as biological control of ticks is challenged by the need for high concentrations of fungal propagules (Fernandes \& Bittencourt, 2008). Accordingly, the present study aimed to select Metarhizium spp. isolates to control $R$. microplus ticks through the analysis of their in vitro virulence and capacity for conidial production.

\section{Material and methods}

\section{Fungal isolates and suspensions}

Metarhizium spp. native Brazilian isolates (Table 1) were obtained from the National Center for Genetic Resources-CENARGEN, EMBRAPA, Brazil and are also deposited at the Agriculture Research Service Collection of Entomopathogenic Fungi (ARSEF) at the Laboratory of Plants, Soil, and Nutrition (Ithaca, NY, USA). As the present study accessed Brazilian genetic heritage, the research was registered at the National System for the Management of Genetic Heritage and Associated Traditional Knowledge (Sis-Gen) under the code AACFDD5.

The fungal isolates were produced on potato dextrose agar (PDA) at $25 \pm 1^{\circ} \mathrm{C}$ and $\geq 80 \%$ relative humidity (RH) for 14 days. Conidia were harvested from culture plates by scraping the medium surface with a scalpel blade and suspended in $30 \mathrm{~mL}$ of polyoxyethylene sorbitan monooleate (Tween 80', Sigma Chemical Co., St. Louis, MO, USA) solution [0.01\% (v/v)]. The conidial suspension was homogenized for 1 min using a vortex mixer, quantified in a hemocytometer and adjusted to $1.0 \times 10^{8}$ conidia $\mathrm{mL}^{-1}$. Serial dilutions were made from the concentration of $10^{8} \mathrm{conidia}^{-\mathrm{mL}^{-1} \text { to }}$ obtain the other concentrations $\left(10^{7}, 10^{6}\right.$, and $10^{5}$ conidia. $\left.\mathrm{mL}^{-1}\right)$. 
Table 1. Fungal isolates used in the experiments.

\begin{tabular}{|c|c|c|c|c|}
\hline Isolate Code & & Species & Substrate/Host & Origin \\
\hline ARSEF & CG/CP & & & \\
\hline ARSEF 552 & - & Metarbizium pingshaense & Lepidoptera & MG, Brazil \\
\hline ARSEF 724 & СР 25 & Metarbizium robertsii & $\begin{array}{l}\text { Cerotoma arcuata } \\
\text { (Coleoptera:Chrysomelidae) }\end{array}$ & GO, Brazil \\
\hline ARSEF 729 & СР 24 & $\begin{array}{l}\text { Metarbizium anisopliae } \\
\text { sensu lato (s.l.) }\end{array}$ & $\begin{array}{l}\text { Deois flavopicta (Homoptera: } \\
\text { Cercopidae) }\end{array}$ & GO, Brazil \\
\hline ARSEF 760 & СР 31 & M. anisopliae s.l. & $\begin{array}{l}\text { Cerotoma arcuata } \\
\text { (Coleoptera: Chrysomelidae) }\end{array}$ & GO, Brazil \\
\hline ARSEF 929 & СР 67 & M. anisopliae s.l. & $\begin{array}{l}\text { Chalcodermus aeneus } \\
\text { (Coleoptera: Curculionidae) }\end{array}$ & GO, Brazil \\
\hline ARSEF 1885 & СР 174 & M. anisopliae s.l. & $\begin{array}{l}\text { Diabrotica sp. } \\
\text { (Coleoptera: Chrysomelidae) }\end{array}$ & GO, Brazil \\
\hline ARSEF 2211 & СР 207 & M. anisopliae s.l. & Soil & SP, Brazil \\
\hline ARSEF 2521 & СР 225 & M. anisopliae s.l. & $\begin{array}{l}\text { Deois sp. } \\
\text { (Homoptera: Cercopidae) }\end{array}$ & PR, Brazil \\
\hline ARSEF 3479 & CG 339 & M. anisopliae s.l. & (Coleoptera: Scarabaeidae) & DF, Brazil \\
\hline ARSEF 3641 & CG 347 & M. anisopliae s.l. & Soil & GO, Brazil \\
\hline ARSEF 3643 & CG 349 & M. anisopliae s.l. & Soil & GO, Brazil \\
\hline
\end{tabular}

ARSEF: Agricultural Research Service Entomopathogenic Fungus Collection, USDA, NY, USA; CG: National Center for Genetic Resources-CENARGEN, EMBRAPA, Brazil. CP: CNPAF National Center for Agricultural Research on Rice and Beans, EMBRAPA, Goiânia, Goiás, Brazil.

Conidial viability was determined by plating an aliquot ( $20 \mu \mathrm{L})$ of the conidia suspension at $10^{5}$ conidia. $\mathrm{mL}^{-1}$ on PDA medium plus $0.05 \%$ chloramphenicol, followed by incubation at $25 \pm 1^{\circ} \mathrm{C}$ and $\geq 80 \% \mathrm{RH}$. Conidial germination was observed by microscope $(\times 200)$ after $24 \mathrm{~h}$ (Alves et al., 1998).

Eggs, larvae, and female ticks were treated with fungal suspensions at $10^{8}$ or $10^{7}$ conidia. $\mathrm{mL}^{-1}$. A Tween $80^{\circ}$ solution $(0.01 \% \mathrm{v} / \mathrm{v})$, without fungus, was used to treat the control group. All bioassays (eggs, larvae, and female ticks) were conducted twice (in different days) with new batches of conidia each time.

\section{Rhipicephalus microplus ticks}

Engorged R. microplus females were collected from the floor of cattle pens holding infested calves with approval of the ethics committee for the use of animals in research - CEUA/IV/ UFRRJ - protocol number 037/2014. The calves had no recent (more than 3 months) contact with any chemical acaricides. Female ticks were taken to the laboratory and washed in a 0.05\% sodium hypochlorite solution for cuticle asepsis. Then they were rinsed in sterile distilled water and dried with sterile paper towels. Part of these female ticks were used for the bioassay, and the other portion was incubated at $27 \pm 1^{\circ} \mathrm{C}$ and relative humidity $\geq 80 \%$ for oviposition and larval hatching.

\section{Bioassays}

\section{Fungal virulence against Rhipicephalus microplus eggs}

Aliquots containing $50 \mathrm{mg}$ of $R$. microplus eggs were weighed and placed into test tubes, which were then sealed with hydrophilic cotton. Each bioassay consisted of three groups (two treatments and one control). Each group had ten test tubes, each containing approximately 1000 $R$. microplus eggs. Experiments were conducted by injecting $1 \mathrm{~mL}$ of conidial suspension into each test tube. The eggs were kept immersed in the injected fluid for $3 \mathrm{~min}$, and the test tube 
was then inverted until all of the conidial suspension was absorbed by the cotton plug. The tubes were maintained at $27 \pm 1^{\circ} \mathrm{C}$ and $\geq 80 \% \mathrm{RH}$ in the dark. The percent of larval hatchability for each tube was visually estimated by microscopic observation $(\times 20)$, with the estimates expressed as percentages varying from 0 to $100 \%$ in $1 \%$ intervals.

\section{Fungal virulence against Rhipicephalus microplus larvae}

The methodology used in the larval bioassay was similar to the methodology described for the bioassay with eggs. Aliquots with $50 \mathrm{mg}$ of eggs were collected from day 1 to day 10 of oviposition, placed in test tubes sealed with cotton plugs and observed daily for 20-25 days to estimate percentage of hatched eggs. Tubes with less than 95\% hatched were discarded. The larval treatment with fungal suspensions was performed on the $15^{\text {th }}$ day after larval hatching (approximately 40 days after oviposition). Each group had ten test tubes, each containing approximately 1000 R. microplus larvae. Larval mortality was recorded at days 5 and 15 after the treatment. The percent of larval mortality for each tube was visually estimated by microscopic observation (×20), with the estimates expressed as percentages varying from 0 to $100 \%$ in $1 \%$ intervals. Larvae that were unable to move were recorded as dead.

\section{Fungal virulence against Rhipicephalus microplus engorged females}

Females ticks were weighed individually and homogeneously distributed according to their weight into the groups of ten females. Each female was immersed individually for three minutes in test tubes with one ml of the fungal suspension. After that, each female was fixed by the dorsal part of the idiosome on Petri dishes using double-sided adhesive tape and then the plates were conditioned in a climatic chamber at $27 \pm 1^{\circ} \mathrm{C}$ and $\mathrm{RH} \geq 80 \%$.

Biological parameters used to evaluate the effects of the different isolates on the engorged females were the initial female weight (IFW), egg mass weight (EMW), and larvae hatching percentage (LHP). The average of each parameter was used to calculate the egg production index (EPI) and the nutritional index (NI) using the equations from Bennett (1974). The percentage of $R$. microplus controlled by the fungal isolates was obtained by the calculation of the estimated reproduction according to Drummond et al. (1971).

Fungal infection was confirmed by incubating dead ticks at $25 \pm 1^{\circ} \mathrm{C}$. Dead ticks were surface sterilized and placed into Petri dishes with moistened filter paper until fungal externalization to verify post-mortem sporulation.

\section{Production of conidia on PDA}

Forty $\mu$ l of fungal suspensions at $10^{6}$ conidia. $\mathrm{mL}^{-1}$ were applied on Petri plates with $23 \mathrm{~mL}$ of PDA and distributed throughout the plate using a Drigalski handle. Six plates were prepared for each isolate. The plates were incubated at $25 \pm 1^{\circ} \mathrm{C}$ and $\mathrm{RH} \geq 80 \%$ for 14 days. Three random cut-offs of $1.256 \mathrm{~cm}^{2}$ were made on the fungal plates and deposited in a test tube with one $\mathrm{mL}$ of Tween $80^{\circ}$ aqueous sterile solution at $0.1 \%(\mathrm{v} / \mathrm{v})$. Tubes were vigorously vortexed for 60 seconds. Conidia quantification was performed using a Neubauer chamber under an optical microscope. The procedure was repeated with all six plates of each fungal isolate. Analysis of conidiogenesis was repeated three times.

\section{Statistical analysis}

The tick bioassays (with eggs, larvae, and engorged females) were installed using a factorial arrangement $(11 \times 2)+1$ from the combination of 11 entomopathogenic fungal isolates applied in two fungal concentrations $\left(10^{7}\right.$ and $10^{8}$ conidia.ml ${ }^{-1}$ ) and an additional treatment without the use of fungus (control treatment). The conidiogenesis experiment (production of conidia on PDA) was carried out using a completely randomized design, with 11 "treatments" (eleven entomopathogenic fungal isolates), six replicates and two samples per experimental unit.

Data were submitted to the Kolmogorov-Smirnov test $(P>0.05)$ to verify the residual normality and to the Bartlett test $(\mathrm{P}>0.05)$ to determine the homogeneity of variance. Having verified these assumptions, the analysis of variance (ANOVA) was conducted. The averages obtained for each fungal isolate and their respective concentrations were compared 
and grouped by the Scott-Knott test at 5\% probability. The comparison between the factorial treatments and the control treatment used the Dunnett test. All analyzes were performed using the software $\mathrm{R}$, version 3.5.2.

\section{Results}

\section{Viability of fungal suspensions}

Conidia of Metarhizium spp. isolates used to treat eggs, larvae, and adult females had approximately $100 \%$ germination after incubation for $24 \mathrm{~h}$ at $25 \pm 1^{\circ} \mathrm{C}$ and $\geq 80 \% \mathrm{RH}$.

\section{Fungal virulence against Rhipicephalus microplus eggs}

Analysis of larval hatching of $R$. microplus eggs exposed or not (control) to the different Metarbizium spp. isolates demonstrated that the different entomopathogenic fungal isolates (F), concentrations $(\mathrm{C})$, and the interaction between these two factors $(\mathrm{F} \times \mathrm{C})$ significantly interfered in the larval hatching (Tables 2 and 3). At the lowest concentration, only Metarbizium spp. ARSEF 552 and ARSEF 760 significantly reduce the larval hatching in comparison with the control group (untreated eggs). At the highest concentration $\left(10^{8}\right.$ conidia. $\left.\mathrm{ml}^{-1}\right)$, most fungal isolates reduced the larval hatching compared to the control group, except ARSEF 2211 and ARSEF 3641. ARSEF 729, ARSEF 760, and ARSEF 929, and ARSEF 3643 exhibited the best results among the tested isolates (Table 3).

\section{Bioassay with Rhipicephalus microplus larvae}

A summary of the variance analysis of larval mortality five and fifteen days after the treatment with 11 fungal isolates and 2 different concentrations is reported in Table 2. Entomopathogenic fungal isolates yielded average larval mortality ranging from 0.1\% to $79.3 \%$ and $7.42 \%$ to $98.9 \%$ five days after the treatment with $10^{7}$ and $10^{8}$ conidia.ml ${ }^{-1}$, respectively. Five days after the treatment,

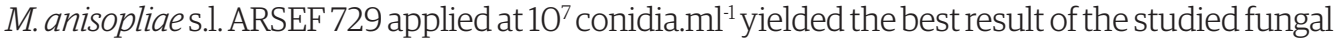
isolates; on the same day, but at the highest concentration, ARSEF 729, ARSEF 760, and ARSEF 3479 caused the highest mortality rates (Table 4).

Table 2. Analysis of variance of Rhipicephalus microplus larval hatching, larval mortality at 5 and 15 days after the fungus treatment, and production of conidia by 11 Metarbizium spp. isolates.

\begin{tabular}{|c|c|c|c|c|c|c|c|}
\hline \multirow{2}{*}{$\begin{array}{l}\text { Sources of } \\
\text { variation }\end{array}$} & \multicolumn{2}{|c|}{ Larval hatching } & \multicolumn{2}{|c|}{ Larval mortality } & & \multicolumn{2}{|c|}{ Production of conidia } \\
\hline & $\begin{array}{l}\text { Degrees of } \\
\text { freedom }\end{array}$ & $\begin{array}{c}\text { Mean } \\
\text { squares }\end{array}$ & $\begin{array}{l}\text { Degrees of } \\
\text { freedom }\end{array}$ & $\begin{array}{c}\text { Mean } \\
\text { squares }\end{array}$ & & $\begin{array}{l}\text { Degrees of } \\
\text { freedom }\end{array}$ & $\begin{array}{l}\text { Mean } \\
\text { squares }\end{array}$ \\
\hline & & & \multicolumn{3}{|c|}{$\begin{array}{c}\text { Days after the } \\
\text { treatment }\end{array}$} & \multirow{2}{*}{\multicolumn{2}{|c|}{$\begin{array}{l}\text { Number } \\
\text { of conidia }\end{array}$}} \\
\hline & & & & 5 & 15 & & \\
\hline Fungal isolates $(\mathrm{F})$ & 10 & $653.4^{* *}$ & 10 & $8341.7^{* *}$ & $3959.1^{* *}$ & 10 & $350748.8^{* *}$ \\
\hline Concentration (C) & 1 & $9164.4^{* *}$ & 1 & $52245.0^{* *}$ & $19738.9^{* *}$ & & \\
\hline $\mathrm{F} \times \mathrm{C}$ & 10 & $540.4^{* *}$ & 10 & $3713.0^{* *}$ & $896.6^{* *}$ & & \\
\hline $\begin{array}{l}\text { Additional } \\
\text { treatment (control) } \\
\times \text { factorial (fungal } \\
\text { treatment in each } \\
\text { concentration) }\end{array}$ & 1 & $1165.7^{* *}$ & 1 & $7161.6^{* *}$ & $45540.0^{* *}$ & & \\
\hline Residual & 138 & 22.9 & 138 & 31.02 & 38.7 & 55 & 2474.8 \\
\hline Total & 160 & & 160 & & & 65 & \\
\hline $\begin{array}{l}\text { Coefficient of } \\
\text { variation }\end{array}$ & & $7.1 \%$ & & $4.52 \%$ & $5.2 \%$ & & $12.3 \%$ \\
\hline
\end{tabular}


Table 3. Average percent of hatching of Rhipicephalus microplus larvae and standard error after the treatment of the eggs with Metarhizium spp. isolates.

\begin{tabular}{|c|c|c|}
\hline \multirow{2}{*}{ Fungal isolates } & \multicolumn{2}{|c|}{ Larval hatching (\%) after the treatments } \\
\hline & $10^{7}$ conidia. $\mathrm{mL}^{-1}$ & $10^{8}$ conidia. $\mathrm{mL}^{-1}$ \\
\hline ARSEF 552 & $88.1 \pm 2.3 \mathrm{Aa}^{*}$ & $83.4 \pm 2.9 \mathrm{Ab}^{*}$ \\
\hline ARSEF 724 & $93.1 \pm 0.7 \mathrm{Ba}$ & $81.8 \pm 2.0 \mathrm{Ab}^{*}$ \\
\hline ARSEF 729 & $88.6 \pm 0.9 \mathrm{Ba}$ & $52.9 \pm 4.1 \mathrm{Aa}^{*}$ \\
\hline ARSEF 760 & $87.7 \pm 1.7 \mathrm{Ba}^{*}$ & $61.4 \pm 0.9 \mathrm{Aa}^{*}$ \\
\hline ARSEF 929 & $88.9 \pm 1.2 \mathrm{Ba}$ & $63.5 \pm 3.2 \mathrm{Aa}^{*}$ \\
\hline ARSEF 1885 & $92.3 \pm 0.5 \mathrm{Ba}$ & $78.6 \pm 3.0 \mathrm{Ab}^{*}$ \\
\hline ARSEF 2211 & $90.1 \pm 0.7 \mathrm{Aa}$ & $91.3 \pm 0.5 \mathrm{Ab}$ \\
\hline ARSEF 2521 & $91.1 \pm 0.5 \mathrm{Ba}$ & $74.3 \pm 1.8 \mathrm{Ab}^{*}$ \\
\hline ARSEF 3479 & $93.5 \pm 0.5 \mathrm{Ba}$ & $85.1 \pm 1.6 \mathrm{Ab}^{*}$ \\
\hline ARSEF 3641 & $89.9 \pm 0.5 \mathrm{Aa}$ & $91.1 \pm 0.4 \mathrm{Ab}$ \\
\hline ARSEF 3643 & $95.1 \pm 0.8 \mathrm{Ba}$ & $65.7 \pm 2.5 \mathrm{Aa}^{*}$ \\
\hline Control & \multicolumn{2}{|c|}{$96.3 \pm 0.5 \%$} \\
\hline MSD Dunnett & \multicolumn{2}{|c|}{$7.83 \%$} \\
\hline
\end{tabular}

Table 4. Average percent of mortality of Rhipicephalus microplus larvae and standard error 5 and 15 days after the treatment with Metarhizium spp. isolates.

\begin{tabular}{|c|c|c|c|c|}
\hline \multirow{3}{*}{ Fungal isolates } & \multicolumn{4}{|c|}{ Fungal concentration and days after the treatment } \\
\hline & \multicolumn{2}{|c|}{5 days } & \multicolumn{2}{|c|}{15 days } \\
\hline & $10^{7}{\text { conidia. } \mathrm{mL}^{-1}}^{-1}$ & $10^{8}$ conidia. $\mathrm{mL}^{-1}$ & $10^{7}$ conidia.mL $L^{-1}$ & $10^{8}$ conidia. $\mathrm{mL}^{-1}$ \\
\hline ARSEF 552 & $8.1 \pm 0.4 \mathrm{Bb}$ & $64.5 \pm 2.9 \mathrm{Ab}^{*}$ & $97.4 \pm 1.3 \mathrm{Aa}^{*}$ & $99.9 \pm 0.07 \mathrm{Aa}^{*}$ \\
\hline ARSEF 724 & $2.4 \pm 0.3 \mathrm{Bd}$ & $67.6 \pm 2.9 \mathrm{Ab}^{*}$ & $62.1 \pm 4.5 \mathrm{Bb}^{*}$ & $99.8 \pm 0.2 \mathrm{Aa}^{*}$ \\
\hline ARSEF 729 & $79.3 \pm 2.1 \mathrm{Aa}^{*}$ & $84.3 \pm 5.1 \mathrm{Aa}^{*}$ & $84.6 \pm 1.3 \mathrm{Aa}^{*}$ & $91.1 \pm 0.5 \mathrm{Aa}^{*}$ \\
\hline ARSEF 760 & $11.1 \pm 0.8 \mathrm{Bb}^{*}$ & $98.9 \pm 0.5 \mathrm{Aa}^{*}$ & $55.7 \pm 1.1 \mathrm{Bb}^{*}$ & $99.8 \pm 0.09 \mathrm{Aa}^{*}$ \\
\hline ARSEF 929 & $15.9 \pm 1.3 \mathrm{Bb}^{*}$ & $63.2 \pm 2.0 \mathrm{Ab}^{*}$ & $97.6 \pm 0.5 \mathrm{Aa}^{*}$ & $99.7 \pm 0.2 \mathrm{Aa}^{*}$ \\
\hline ARSEF 1885 & $3.5 \pm 0.4 \mathrm{Ab}$ & $7.4 \pm 1.1 \mathrm{Ac}$ & $68.9 \pm 4.3 \mathrm{Bb}^{*}$ & $99.4 \pm 0.3 \mathrm{Aa}^{*}$ \\
\hline ARSEF 2211 & $0.1 \pm 0.02 \mathrm{Ab}$ & $7.8 \pm 0.8 \mathrm{Ac}$ & $23.9 \pm 1.3 \mathrm{Bc}^{*}$ & $51.6 \pm 1.3 \mathrm{Ab}^{*}$ \\
\hline ARSEF 2521 & $3.9 \pm 0.5 \mathrm{Ab}$ & $15.0 \pm 1.1 \mathrm{Ac}^{*}$ & $72.1 \pm 6.9 \mathrm{Bb}^{*}$ & $97.0 \pm 0.5 \mathrm{Aa}^{*}$ \\
\hline ARSEF 3479 & $8.6 \pm 1.2 \mathrm{Bb}^{*}$ & $92.8 \pm 1.0 \mathrm{Aa}^{*}$ & $60.4 \pm 3.0 \mathrm{Bb}^{*}$ & $99.4 \pm 0.34 \mathrm{Aa}^{*}$ \\
\hline ARSEF 3641 & $4.8 \pm 1.1 \mathrm{Ab}$ & $13.5 \pm 1.5 \mathrm{Ac}^{*}$ & $65.4 \pm 4.1 \mathrm{Bb}^{*}$ & $96.1 \pm 1.2 \mathrm{Aa}^{*}$ \\
\hline ARSEF 3643 & $19.3 \pm 2.1 \mathrm{Bb}^{*}$ & $47.0 \pm 5.0 \mathrm{Ab}^{*}$ & $96.0 \pm 1.4 \mathrm{Aa}^{*}$ & $99.6 \pm 0.4 \mathrm{Aa}^{*}$ \\
\hline Control & $0.0 \pm 0.0 \%$ & & $0.2 \pm 0.06 \%$ & \\
\hline MSD Dunnett & $8.4 \%$ & & $9.4 \%$ & \\
\hline
\end{tabular}

Averages on the same day followed by the same lowercase letters in the columns and uppercase letters in the lines do not differ statistically by Skott-Knott test $(P \geq 0.05) ;{ }^{*}=$ significant difference between the fungus treatment and the control treatment; MSD Dunnett: minimal significant difference for the Dunnett test $(P \leq 0.05)$. 
Fifteen days after the treatment, entomopathogenic fungal isolates yielded average larval mortality ranging from $23.9 \%$ to $97.6 \%$ and $51.6 \%$ to $99.9 \%$ followed by the treatment with $10^{7}$ and $10^{8}$ conidia.ml' ${ }^{-1}$, respectively. Metarbizium spp. ARSEF 552, ARSEF 729, ARSEF 929, and ARSEF 3643 applied at $10^{7}$ conidia.ml ${ }^{-1}$ yielded the highest larval mortality, 15 days after the treatment. On the same day, but at the highest concentration, almost all fungal isolates caused larval mortality greater than 90\%; ARSEF 2211 was the exception, causing significantly less mortality than the other isolates (Table 4).

\section{Bioassay with Rhipicephalus microplus engorged females}

Analysis of the biological assays with $R$. microplus engorged females exposed to different Metarhizium spp. isolates and concentrations are displayed in Tables 5 and 6. The analysis of variance showed that the different fungal isolates and the two concentrations used negatively impacted the EMW, LHP, EPI, and NI (Table 5) but not the larval hatching. There was no statistical difference in the initial weight of $R$. microplus engorged females used in the groups, which demonstrates that the changes observed in their biological parameters were a result of the treatments with entomopathogenic fungi.

Metarbizium spp. ARSEF 552, ARSEF 724, ARSEF 929, ARSEF 3641, and ARSEF 3643 significantly reduced the EMW from $R$. microplus females treated with $10^{7}$ conidia.ml $^{-1}$ in comparison to the other isolates and the control (untreated) group. At the highest fungal concentration, the isolates ARSEF 552, ARSEF 729, ARSEF 3641, and ARSEF 3643 yielded the best results for EMW reduction (Table 6). The fungal treatments similarly affected EPI and NI. For both fungal concentrations, ARSEF 552, ARSEF 3641, and ARSEF 3643 significantly reduced the EPI and NI in comparison to the control (untreated) group. M. anisopliae s.l. ARSEF 729 used at $10^{7}$ conidia. $\mathrm{ml}^{-1}$ or $10^{8}$ conidia.ml ${ }^{-1}$ yielded a lower EPI than the control group; however, this isolate only reduced the NI at the highest fungal concentration (Table 6). The isolates ARSEF 724 and ARSEF 929 significantly reduced these indexes only when used at $10^{7}$ conidia. $\mathrm{ml}^{-1}$. On the other hand, ARSEF 1885 and ARSEF 2521 reduced the EPI only when used at the highest concentration (Table 6).

The percent of tick control ranged from $5.32 \%$ to $70.83 \%$, and the fungal isolates that yielded the best tick control rates were ARSEF 3643, ARSEF 3641, and ARSEF 729 with tick control of 70.83\%, 62.87\%, and 64.27\%, respectively (Table 6).

Table 5. Analysis of variance for the biological parameters of female Rhipicephalus microplus tick after the treatment with 11 fungal isolates and two different concentrations.

\begin{tabular}{|c|c|c|c|c|c|}
\hline \multirow{2}{*}{ Sources of variation } & \multirow{2}{*}{$\begin{array}{l}\text { Degrees of } \\
\text { freedom }\end{array}$} & \multicolumn{4}{|c|}{ Mean squares } \\
\hline & & EMW & LHP & EPI & NI \\
\hline Fungal isolates $(\mathrm{F})$ & 10 & $0.008^{* *}$ & $1223.6^{* *}$ & $1438.13^{* *}$ & $1573.14^{* *}$ \\
\hline Concentration (C) & 1 & $0.005^{* *}$ & $4719.8^{* *}$ & $936.36^{* *}$ & $1137.39 * *$ \\
\hline $\mathrm{F} \times \mathrm{C}$ & 10 & $0.002^{* *}$ & $787.8^{\text {ns }}$ & $490.36^{* *}$ & $697.87^{* *}$ \\
\hline $\begin{array}{l}\text { Additional treatment } \\
\text { (control) × factorial } \\
\text { (fungal treatment in } \\
\text { each concentration) }\end{array}$ & 1 & $0.013^{* *}$ & $952.2^{\text {ns }}$ & $22.84^{* *}$ & $2080.95^{* *}$ \\
\hline Residual & 207 & 0.0008 & 440.1 & 117.46 & 158.74 \\
\hline Total & 229 & & & & \\
\hline $\begin{array}{l}\text { Coefficient of } \\
\text { variation (\%) }\end{array}$ & & 13.07 & 16.20 & 16.41 & 14.26 \\
\hline
\end{tabular}

** = significant effect at $1 \%$ probability. Ns = not significant. 


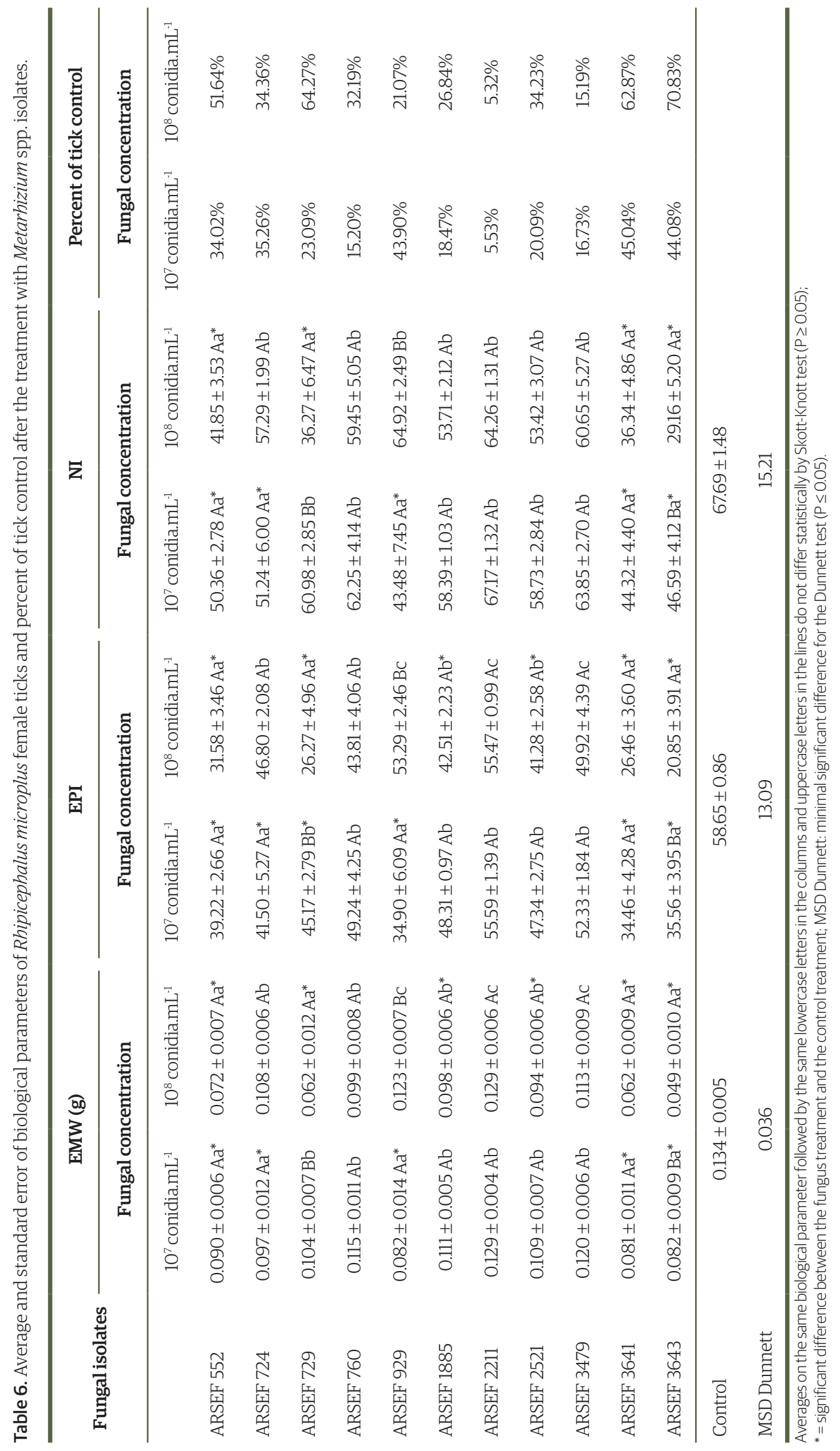




\section{Production of conidia on PDA}

Analysis of the production of conidia on PDA by the Metarbizium spp. isolates used in the present study is reported in tables 2 and 7 . Analysis of variance demonstrated a significant difference in the production of conidia between the different fungal isolates analyzed (Table 2). Among the studied isolates, the ones with the highest conidial production on PDA were ARSEF 3641 and ARSEF 552 (Table 7), followed by ARSEF 1885, ARSEF 2521, ARSEF 3643, and ARSEF 2211, the last three with similar conidiogenesis. The lowest conidial production on PDA was observed for ARSEF 3479 and ARSEF 929 (Table 7).

\section{Discussion}

Alternative control of ticks has become an attractive approach due to increased concerns about populations that are resistant to chemical acaricides as well as environmental, meat, and milk contamination due to the inappropriate use of these chemicals (Klafke et al., 2017; Samish et al., 2004). The search for alternative methods to control R. microplus is currently a major challenge for researchers due to its importance in the world livestock industry. In this context, biological control of arthropods using entomopathogenic fungi has received great prominence.

Several studies have demonstrated the effectiveness of the fungi Metarhizium for tick control (Angelo et al., 2010; Beys-da-Silva et al., 2020; Camargo et al., 2012; Fernandes \& Bittencourt, 2008; Mesquita et al., 2020; Perinotto et al., 2017), including under field conditions (Camargo et al., 2016; Kaaya et al., 2011; Marciano et al., 2020; Samish et al., 2014). This fungus acts mainly through the germination of conidia on the arthropod's cuticle followed by the formation of germ tube and appressorium on the cuticle. After a series of enzymatic reactions and the mechanical apparatus of fungal structures, the fungus penetrates the host's hemocele. Once inside the tick, hemocele colonization reduces the function of ticks' body, which can lead to its death (Bittencourt et al., 1999). Establishing how well a fungal isolate can infect and cause disease in ticks is an important step to identify isolates that may be effective in the field. Accordingly, the experimental method used here provided a general estimate as to how well Brazilian native Metarhizium spp. isolates could infect tick eggs, larvae, and females.

The viability of the conidia that were used to treat the ticks is extremely important, since it allows the successful onset of fungus penetration of the tick cuticle (Bittencourt et al., 1999; Schrank \& Vainstein, 2010). The suspensions used in the present study had 100\% conidial germination, supporting the infective capacity of the conidia that were used in the treatments.

Table 7. Average and standard error of production of aerial conidia from Metarbizium spp. isolates on potato dextrose agar medium.

\begin{tabular}{cc}
\hline Fungal isolates & $\mathbf{N} \times \mathbf{1 0}^{\mathbf{5}}$ conidia.mL $^{-1}$ \\
\hline ARSEF 552 & $706.8 \pm 33.7 \mathrm{a}$ \\
ARSEF 724 & $293.7 \pm 7.9 \mathrm{~d}$ \\
ARSEF 729 & $267.6 \pm 13.0 \mathrm{~d}$ \\
ARSEF 760 & $282.3 \pm 11.9 \mathrm{~d}$ \\
ARSEF 929 & $21.4 \pm 1.9 \mathrm{e}$ \\
ARSEF 1885 & $608.9 \pm 35.9 \mathrm{~b}$ \\
ARSEF 2211 & $493.0 \pm 22.9 \mathrm{c}$ \\
ARSEF 2521 & $518.5 \pm 15.9 \mathrm{c}$ \\
ARSEF 3479 & $37.8 \pm 2.6 \mathrm{e}$ \\
ARSEF 3641 & $712.1 \pm 24.3 \mathrm{a}$ \\
ARSEF 3643 & $498.3 \pm 19.6 \mathrm{c}$ \\
\hline
\end{tabular}

Averages followed by the same lowercase letters do not differ statistically by Skott-Knott test ( $P \geq 0.05)$.

Aos autores: 
Metarbizium spp. used here were able to infect R. microplus eggs, reducing the larval hatchability, particularly at the highest concentration. Nevertheless, compared to previously published studies (Fernandes \& Bittencourt, 2008) these isolates were not as virulent as expected for R. microplus eggs. The tick larval stage is considered the life stage most susceptible to entomopathogenic fungi. In the present study, most isolates (except $M$. anisopliae s.l. ARSEF 2211) greatly affected R. microplus larvae survival fifteen days after the treatment with $10^{8}$ conidia.ml-1 although five days after the treatment with this same dose some isolates already achieved remarkably good results (i.e., ARSEF 760, ARSEF 3479, and ARSEF 729).

The virulence survey was very useful to identify isolates with high virulence for $R$. microplus ticks. Four isolates showed exceptional results as biocontrol agents of female ticks (i.e., ARSEF 552, ARSEF 729, ARSEF 3641, and ARSEF 3643). These isolates negatively impacted all biological parameters that were analyzed and exhibited the best tick control percentage. Interestingly, some isolates exhibited excellent results for specific life stages (for example, ARSEF 3641 for $R$. microplus females, but not eggs or larvae); nevertheless, one of these isolates (i.e., M. anisopliae s.l. ARSEF 729) was virulent for all stages (eggs, larva, and females) when applied at the highest concentration. Accordingly, this isolate can be considered a promising candidate to be used against $R$. microplus parasitic phases (i.e., applied on the host) and against the non-parasitic phases (i.e., applied to control the life stages that are found on the ground). Note that the fungal conidia concentration usually tested against ticks, which is $10^{8}$ conidia $\mathrm{ml}^{-1}$, is higher than the ones tested for insects, which is often $10^{4}$ or $10^{5}$ conidia.ml'-1 (Roberts \& St Leger, 2004). In the present study, considering both virulence for R. microplus ticks and the capacity of conidial production on PDA, ARSEF 3643 stands out as a promising isolate for tick control.

Most mycoinsecticides produced currently in Brazil are based on aerial conidia (Mascarin et al., 2019). Several variables, including the type of substrates, the application of modified atmospheres, temperature, and light can impact aerial conidia production (number and quality of conidia) of Metarbizium (Barra-Bucarei et al., 2016; Garcia-Ortiz et al., 2015; Lopes et al., 2018). The capacity for conidia production is important especially for tick control that requires high concentration of conidia; however, highly virulent isolates do not always have high rates of conidiogenesis as observed for ARSEF 729. Thus, searching for technologies that improve aerial conidia production is necessary to afford the commercial availability of such mycoacaricides.

New strategies for tick control are necessary and the use of entomopathogenic fungi against different stages of tick life is one of them (Wassermann et al., 2016). The genetic variability among the entomopathogenic fungal isolates explains the different virulent potentials for insect and arachnid pest control, highlighting the importance of studies that select isolates with efficient characteristics for biological control programs of agricultural and veterinary pests (Barci et al., 2009). The present study explored the conidiogenesis capacity of different Brazilian Metarbizium spp. isolates and their virulence to $R$. microplus eggs, larvae, and engorged females. This is extremely important, since studies involving the selection of convenient isolates for field application is imperative for the successful biological control of ticks.

\section{Acknowledgements}

This study was financed in part by the Coordenação de Aperfeiçoamento de Pessoal de Nivel Superior-Brasil (CAPES)-Finance Code 001. This research was supported by grants of CNPq and Carlos Chagas Filho Foundation for Research of the State of Rio de Janeiro (FAPERJ). We appreciate the advices of the statistician Dr. João Luiz Lopes Monteiro Neto. V.R.E.P. Bittencourt is a CNPq researcher.

\section{Ethics statement}

Engorged females of Rhipicephalus microplus used in the present study were collected from the floor of cattle pens holding artificially infested calves. This received approval of the ethics committee for the use of animals in research - CEUA/IV/UFRRJ- protocol number 037/2014. 


\title{
Financial support
}

GAJ received a scholarship from CAPES (Coordenação de Aperfeiçoamento de Pessoal de Nível Superior); MGC received a pos doc schoparship from FAPERJ (Fundação de Amparo à Pesquisa do Estado do Rio de Janeiro); VREPB - received a researcher scholarship from CNPq (Conselho Nacional de Desenvolvimento Científico e Tecnológico); PSG and WMSP none.

\section{Conflict of interests}

The authors declare that there is no conflict of interest.

\section{Authors' contributions}

GAJ and VREPB - Conceived and designed the experiments. GAJ and MGC - Performed the experiments. GAJ, PSG, MGC and WMSP - Analyzed the data. VREPB - Contributed with reagents/materials/analysis tools. GAJ, MGC, PSG and WMSP - Contributed to the writing of the manuscript.

\section{Availability of complementary results}

\author{
There are no complementary results.
}

This study was carried out at Estação Parasitológica W. O. Neitz, no Departamento de Parasitologia Animal do Instituto de Veterinária da Universidade Federal Rural do Rio de Janeiro (UFRRJ), Seropédica, RJ, Brasil.

\section{References}

Alves, S. B., Moino, A., Almeida, J. E. M., \& Alves, S. B. (1998). Controle microbiano de insetos. FEALQ. Impacto ambiental de entomopatógenos.

Andreotti, R., Guerrero, F. D., Soares, M. A., Barros, J. C., Miller, R. J., \& Léon, A. P. D. (2011). Acaricide resistance of Rhipicephalus (Boophilus) microplus in state of Mato Grosso do Sul, Brazil. Revista Brasileira de Parasitologia Veterinária, 20(2), 127-133. http://dx.doi.org/10.1590/S1984-29612011000200007. PMid:21722487.

Angelo, I. C., Fernandes, É. K., Bahiense, T. C., Perinotto, W. M., Moraes, A. P. R., Terra, A. L., \& Bittencourt, V. R. E. P. (2010). Efficiency of Lecanicillium lecanii to control the tick Rhipicephalus microplus. Veterinary Parasitology, 172(3-4), 317-322. http://dx.doi.org/10.1016/j.vetpar.2010.04.038. PMid:20605335.

Bahiense, T. C., Fernandes, É. K. K., \& Bittencourt, V. R. E. P. (2006). Compatibility of the fungus Metarhizium anisopliae and deltamethrin to control a resistant strain of Boophilus microplus tick. Veterinary Parasitology, 141(3-4), 319-324. http://dx.doi.org/10.1016/j.vetpar.2006.05.011. PMid:16815637.

Barci, L. A., Almeida, J. E. M. D., Nogueira, A. H., Zappelini, L. O., \& Prado, A. P. D. (2009). Seleção de isolados do fungo entomopatogênico Beauveria bassiana (Ascomycetes: Clavicipitaceae) para o controle de Rhipicephalus (Boophilus) microplus (Acari: Ixodidae). Revista Brasileira de Parasitologia Veterinária, 18(Suppl 1), 7-13. http:// dx.doi.org/10.4322/rbpv.018e1002. PMid:20040184.

Barra-Bucarei, L., Vergara, P., \& Cortes, A. (2016). Conditions to optimize mass production of Metarhizium anisopliae (Metschn.) Sorokin 1883 in different substrates. Chilean Journal of Agricultural Research, 76(4), 448-454. http://dx.doi.org/10.4067/S0718-58392016000400008.

Bennett, G. F. (1974). Oviposition of Boophilus microplus (Canestrini) (Acarida: Ixodidae). I. Influence of tick size on egg production. Acarologia, 16(1), 52-61. PMid:4463680.

Beys-da-Silva, W. O., Rosa, R. L., Berger, M., Coutinho-Rodrigues, C. J., Vainstein, M. H., Schrank, A., Bittencourt, V. R. E. P., \& Santi, L. (2020). Updating the application of Metarhizium anisopliae to control cattle tick Rhipicephalus microplus (Acari: Ixodidae). Experimental Parasitology, 208, 107812. http://dx.doi.org/10.1016/j. exppara.2019.107812. PMid:31809704.

Bischoff, J. F., Rehner, S. A., \& Humber, R. A. (2009). A multilocus phylogeny of the Metarbizium anisopliae lineage. Mycologia, 101(4), 512-530. http://dx.doi.org/10.3852/07-202. PMid:19623931.

Bittencourt, V. R. E. P., Mascarenhas, A. G., \& Faccini, J. L. H. (1999). Mecanismo de infecção do fungo Metarhizium anisopliae no carrapato Boophilus microplus em condições experimentais. Ciência Rural, 351-354(2), 351-354. http://dx.doi.org/10.1590/S0103-84781999000200028.

Bittencourt, V. R. E. P., Massard, C. L., \& Lima, A. F. (1994a). Ação do fungo Metarhizium anisopliae (Metschnikoff, 1879) Sorokin, 1883, em ovos e larvas do carrapato Boophilus microplus (Canestrini, 1887). Revista Universidade Rural. Série Ciências da Vida, 16, 41-47. 
Bittencourt, V. R. E. P., Massard, C. L., \& Lima, A. F. (1994b). Ação do fungo Metarbizium anisopliae sobre a fase não parasitária do ciclo biológico de Boophilus microplus. Revista Universidade Rural. Série Ciências da Vida, 16, 49-55.

Camargo, M. G., Golo, P. S., Angelo, I. C., Perinotto, W. M., Sá, F. A., Quinelato, S., \& Bittencourt, V. R. (2012). Effect of oil-based formulations of acaripathogenic fungi to control Rhipicephalus microplus ticks under laboratory conditions. Veterinary Parasitology, 188(1-2), 140-147. http://dx.doi.org/10.1016/j.vetpar.2012.03.012. PMid:22480883.

Camargo, M. G., Marciano, A. F., Sá, F. A., Perinotto, W. M., Quinelato, S., Gôlo, P. S., Angelo, I. C., Prata, M. C. A., \& Bittencourt, V. R. (2014). Commercial formulation of Metarbizium anisopliae for the control of Rhipicephalus microplus in a pen study. Veterinary Parasitology, 205(1-2), 271-276. http://dx.doi.org/10.1016/j.vetpar.2014.07.011. PMid:25086495.

Camargo, M. G., Nogueira, M. R., Marciano, A. F., Perinotto, W. M., Coutinho-Rodrigues, C. J., Scott, F. B., Angelo, I. C., Prata, M. C. A., \& Bittencourt, V. R. (2016). Metarbizium anisopliae for controlling Rhipicephalus microplus ticks under field conditions. Veterinary Parasitology, 223, 38-42. http://dx.doi.org/10.1016/j.vetpar.2016.04.014. PMid:27198775.

Drummond, R. O., Gladney, W. J., Whetstone, T. M., \& Ernst, S. E. (1971). Laboratory testing of insecticides for control of the winter tick. Journal of Economic Entomology, 64(3), 686-688. http://dx.doi.org/10.1093/ jee/64.3.686. PMid:5558278.

Fernandes, É. K. K., \& Bittencourt, V. R. E. P. (2008). Entomopathogenic fungi against South American tick species. In J. Bruin \& L. P. S. van der Geest (Eds.), Diseases of Mites and Ticks (pp. 71-93). Springer. http://dx.doi. org/10.1007/978-1-4020-9695-2_8

Garcia-Ortiz, N., Tlecuitl-Beristain, S., Favela-Torres, E., \& Loera, O. (2015). Production and quality of conidia by Metarbizium anisopliae var. lepidiotum: Critical oxygen level and period of mycelium competence. Applied Microbiology and Biotechnology, 99(6), 2783-2791. http://dx.doi.org/10.1007/s00253-014-6225-2. PMid:25472433.

Grisi, L., Leite, R. C., Martins, J. R. D. S., Barros, A. T. M. D., Andreotti, R., Cançado, P. H. D., León, A. A. P., Pereira, J. B., \& Villela, H. S. (2014). Reassessment of the potential economic impact of cattle parasites in Brazil. Revista Brasileira de Parasitologia Veterinária, 23(2), 150-156. http://dx.doi.org/10.1590/S1984-29612014042. PMid:25054492.

Kaaya, G. P., Samish, M., Hedimbi, M., Gindin, G., \& Glazer, I. (2011). Control of tick populations by spraying Metarbizium anisopliae conidia on cattle under field conditions. Experimental \& Applied Acarology, 55(3), 273-281. http://dx.doi.org/10.1007/s10493-011-9471-3. PMid:21725837.

Klafke, G. (2008). Resistência de Rhipicephalus (boophilus) microplus contra os carrapaticidas. In M. C. Pereira, M. B. Labruna, M. P. J. Szabó \& G. M. Klafke (Eds.), Rhipicephalus (Boophilus) microplus Biologia, Controle e Resistência (pp. 81-159). MedVet Livros.

Klafke, G., Webster, A., Dall Agnol, B., Pradel, E., Silva, J., de La Canal, L. H., Becker, M., Osório, M. F., Mansson, M., Barreto, R., Scheffer, R., Souza, U. A., Corassini, V. B., Dos Santos, J., Reck, J., \& Martins, J. R. (2017). Multiple resistance to acaricides in field populations of Rhipicephalus microplus from Rio Grande do Sul state, Southern Brazil. Ticks and Tick-Borne Diseases, 8(1), 73-80. http://dx.doi.org/10.1016/j.ttbdis.2016.09.019. PMid:27717758.

Lopes, R. B., Faria, M., \& Glare, T. R. (2018). A nonconventional two-stage fermentation system for the production of aerial conidia of entomopathogenic fungi utilizing surface tension. Journal of Applied Microbiology, 126(1), 155-164. http://dx.doi.org/10.1111/jam.14137. PMid:30353989.

Marciano, A. F., Golo, P. S., Coutinho-Rodrigues, C. J. B., Camargo, M. G., Fiorotti, J., Mesquita, E., Corrêa, T. A., Perinotto, W. M. S., \& Bittencourt, V. R. E. P. (2020). Metarbizium anisopliae sensu lato (sl) oil-in-water emulsions drastically reduced Rhipicephalus microplus larvae outbreak population on artificially infested grass. Medical and Veterinary Entomology, 34(4), 488-492. http://dx.doi.org/10.1111/mve.12445. PMid:32293047.

Mascarin, G. M., Lopes, R. B., Delalibera Junior, İ., Fernandes, É. K. K., Luz, C., \& Faria, M. (2019). Current status and perspectives of fungal entomopathogens used for microbial control of arthropod pests in Brazil. Journal of Invertebrate Pathology, 165, 46-53. http://dx.doi.org/10.1016/j.jip.2018.01.001. PMid:29339191.

Mesquita, E., Marciano, A. F., Corval, A. R., Fiorotti, J., Corrêa, T. A., Quinelato, S., Bittencourt, V. R. E. P., \& Golo, P. S. (2020). Efficacy of a native isolate of the entomopathogenic fungus Metarbizium anisopliae against larval tick outbreaks under semifield conditions. BioControl, 65, 353-362. http://dx.doi.org/10.1007/s10526-020-10006-1.

Perinotto, W. M. S., Angelo, I. C., Golo, P. S., Camargo, M. G., Quinelato, S., Santi, L., Vainstein, M. H., Beys da Silva, W. O., Salles, C. M. C., \& Bittencourt, V. R. E. P. (2014). Metarhizium anisopliae (Deuteromycetes: Moniliaceae) Pr1 activity: biochemical marker of fungal virulence in Rhipicephalus microplus (Acari: Ixodidae). Biocontrol Science and Technology, 24(2), 123-132. http://dx.doi.org/10.1080/09583157.2013.847903.

Perinotto, W. M. S., Angelo, I. C., Golo, P. S., Camargo, M. G., Quinelato, S., Sá, F. A., Coutinho Rodrigues, C. J. B., Marciano, A. F., Monteiro, C. M. O., \& Bittencourt, V. R. E. P. (2017). In vitro pathogenicity of different Metarhizium anisopliae sl isolates in oil formulations against Rhipicephalus microplus. Biocontrol Science and Technology, 27(3), 338-347. http://dx.doi.org/10.1080/09583157.2017.1289151.

Quinelato, S., Golo, P. S., Perinotto, W. M., Sá, F. A., Camargo, M. G., Angelo, I. C., Moraes, A. M. L., \& Bittencourt, V. R. (2012). Virulence potential of Metarbizium anisopliae sl isolates on Rhipicephalus (Boophilus) microplus larvae. Veterinary Parasitology, 190(3-4), 556-565. http://dx.doi.org/10.1016/j.vetpar.2012.06.028. PMid:22840642. 
Reck, J., Klafke, G. M., Webster, A., Dall'Agnol, B., Scheffer, R., Souza, U. A., Corassini, V. B., Vargas, R., dos Santos, J. S., \& Martins, J. R. (2014). First report of fluazuron resistance in Rhipicephalus microplus: A field tick population resistant to six classes of acaricides. Veterinary Parasitology, 201(1-2), 128-136. http://dx.doi.org/10.1016/j. vetpar.2014.01.012. PMid:24560364.

Roberts, D. W., \& St Leger, R. J. (2004). Metarbizium spp., cosmopolitan insect pathogenic fungi: Mycological aspects. Advances in Applied Microbiology, 54,1-70. http://dx.doi.org/10.1016/S0065-2164(04)54001-7. PMid:15251275.

Samish, M., Ginsberg, H., \& Glazer, I. (2004). Biological control of ticks. Parasitology, 129(Suppl), S389-S403. http://dx.doi.org/10.1017/S0031182004005219. PMid:15938520.

Samish, M., Rot, A., Ment, D., Barel, S., Glazer, I., \& Gindin, G. (2014). Efficacy of the entomopathogenic fungus Metarbizium brunneum in controlling the tick Rhipicephalus annulatus under field conditions. Veterinary Parasitology, 206(3-4), 258-266. http://dx.doi.org/10.1016/j.vetpar.2014.10.019. PMid:25468024.

Schrank, A., \& Vainstein, M. H. (2010). Metarhizium anisopliae enzymes and toxins. Toxicon, 56(7), 1267-1274. http://dx.doi.org/10.1016/j.toxicon.2010.03.008. PMid:20298710.

Thomas, M. B., \& Read, A. F. (2007). Fungal bioinsecticide with a sting. Nature Biotechnology, 25(12), 1367-1368. http://dx.doi.org/10.1038/nbt1207-1367. PMid:18066026.

Wassermann, M., Selzer, P., Steidle, J. L., \& Mackenstedt, U. (2016). Biological control of Ixodes ricinus larvae and nymphs with Metarhizium anisopliae blastospores. Ticks and Tick-Borne Diseases, 7(5), 768-771. http://dx.doi. org/10.1016/j.ttbdis.2016.03.010. PMid:27005430.

Webster, A., Reck, J., Santi, L., Souza, U. A., Dall'Agnol, B., Klafke, G. M., Beys-da-Silva, W. O., Martins, J. R., \& Schrank, A. (2015). Integrated control of an acaricide-resistant strain of the cattle tick Rhipicephalus microplus by applying Metarbizium anisopliae associated with cypermethrin and chlorpyriphos under field conditions. Veterinary Parasitology, 207(3-4), 302-308. http://dx.doi.org/10.1016/j.vetpar.2014.11.021. PMid:25577676. 